\title{
The effect of treating wheat with Ethrel in conjunction with some fungicides on the susceptibility to fungal diseases and on the root zone mycoflora of this plant*
}

\author{
MARIAN MICHNIEWICZ, ANTONI ROŻEJ, EWELINA CZERWIŃSKA
}

\author{
Institute of Biology, Copernicus University, \\ Gagarina 9, 87-100 Toruń, Poland
}

(Received: January 26, 1987)

\begin{abstract}
Wheat cv. Grana grown under field conditions, in the early phase of the first node formation, was sprayed with Ethrel $\left(0.35 \mathrm{ml} / \mathrm{m}^{2}\right)$ and with the fungicides: Sportak $45 \mathrm{EC}$ $\left(0.1 \mathrm{ml} / \mathrm{m}^{2}\right)$ and Bayleton Triple $\left(0.2 \mathrm{~g} / \mathrm{m}^{2}\right)$ - separately and in conjunction with Ethrel. It was found that Ethrel reduced the plant's susceptibility to infection by Cercosporella herpotrichoides and by species of the genus Fusarium. The fungicides were more active and also reduced the susceptibility to infection by Erysiphe graminis and Puccinia triticina. The fungistatic effect of Ethrel and Sportak was synergistic only in the case of Cercosporella herpotrichoides. Other interactions between Ethrel and fungicides were not found. Ethrel and fungicides only slightly affected the mycoflora of the root but they completely eliminated the fungi of the genus Mucor from the rhizosphere and reduced the participation of isolates of the genus Alternaria and Cladosporium in the rhizosphere and rhizoplane of wheat. The fungicides were more active than Ethrel. An interaction between Ethrel and fungicides in the reduction of fungi of the genus Fusarium in the rhizosphere was shown.
\end{abstract}

\section{INTRODUCTION}

In our earlier investigations (Michniewicz et al., 1986) it was found that Ethrel - a compound widely used in agriculture (Nickell, 1982) which acts as a lodging reducer in grains (Hoffmann, 1978) used in field cultivation of wheat inhibited the development of some fungal pathogens.

The present work is a continuation of those investigations on the possibility of using Ethrel to prevent infection of wheat by fungal pathogens. Its aim was to study the influence of this preparation on the activity of two broad spectrum fungicides, viz. Sportak and Bayleton Triple. We also tried to find out what effect that treatment had on the root zone mycoflora.

* This study was financed through CPBP 05.02 . 


\section{MATERIAL AND METHODS}

Field experiments were carried out in 1984-1986. The experimental material was winter wheat cv. Grana in $4 \mathrm{~m}^{2}$ plots on the Copernicus University farm at Koniczynka near Toruń.

The plants in the early phase of first node formation were sprayed with Ethrel (Amchem) at $1000 \mathrm{ppm}$, dosage $0.35 \mathrm{ml} / \mathrm{m}^{2}$, and with the fungicides: Sportak 45 EC (F.B.C.) at $800 \mathrm{ppm} 0.1 \mathrm{ml} / \mathrm{m}^{2}$ and Bayleton Triple (Bayer) at $1600 \mathrm{ppm}, 0.2 \mathrm{~g} / \mathrm{m}^{2}$ (in accordance with the producers' directions). In other variants, the plants were sprayed with Ethrel in conjunction with Sportak or Bayleton. Tween $20,0.05 \%$, was used in the preparations of the solutions.

The degree of infection by Cercosporella herpotrichoides and by species of the genus Fusarium was determined at the time of coming into ear; and infection by Erysiphe graminis and Puccinia triticina was determined when the grains were in the yellow-ripe stage. The way of estimating the infection and the methods of calculation have been described in an earlier paper (Michniewicz et al. 1986).

Each experiment was repeated four times. The effect of the infection of wheat by fungal pathogens was determined on 400 plants in each variant of the experiment (100 plants from each plot).

The effect of the treatment used on the composition of the mycoflora of the wheat's rhizosphere and rhizoplane was also studied. The method of isolating the fungi has been described in an earlier paper (Michniewicz et al. 1986). The fungi were identified after two-week incubation at a temperature of $22^{\circ} \mathrm{C}$ on a glucose-potato medium.

This paper presents representative results from 1985, statistically analysed by Student's method.

\section{RESULTS AND DISCUSSION}

The results presented here confirm in principle the results of our earlier research saying that Ethrel at a concentration of $1000 \mathrm{ppm}$ applied on a field wheat crop reduced the plant's sensitivity of Cercosporella herpotrichoides and species of the genus Fusarium, while increasing its sensitivity to Erysiphe graminis and Puccinia triticina.

The fungicides Sportak and Bayleton inhibited the development of the fungi under study, their effect being stronger than that of Ethrel. This inhibitory effect is particularly pronounced with regard to the degree of infection (Table 1), and less so with regard to the percentage on the plants affected. In the case of Erysiphe graminis, the effect on the number of plants affected was insignificant.

The fungistatic effect of Ethrel and Sportak on Cercosporella herpotrichoi- 
Table 1

Effect of the treatment of wheat with Ethrel and fungicides on the degree of injury (in p.c.) of plants by pathogenic fungi

\begin{tabular}{|c|c|c|c|c|c|c|c|c|c|}
\hline \multirow[b]{2}{*}{ Pathogen } & \multicolumn{6}{|c|}{ Treatment } & \multicolumn{3}{|c|}{ LSD at $P$} \\
\hline & $\mathrm{H}_{2} \mathrm{O}$ & Ethrel & Sportak & $\begin{array}{l}\text { Sportak } \\
+ \text { Ethrel }\end{array}$ & Bayleton & $\begin{array}{l}\text { Bayleton } \\
+ \text { Ethrel }\end{array}$ & 0.001 & 0.01 & 0.05 \\
\hline $\begin{array}{l}\text { Cercosporella } \\
\text { herpotrichoides }\end{array}$ & $\begin{array}{c}32.5 \\
(100.0)\end{array}$ & $\begin{array}{c}27.1 \\
(83.4)\end{array}$ & $\begin{array}{c}26.0 \\
(80.0)\end{array}$ & $\begin{array}{c}21.9 \\
(67.4)\end{array}$ & $\begin{array}{c}24.7 \\
(76.0)\end{array}$ & $\begin{array}{c}28.7 \\
(88.3)\end{array}$ & 9.25 & 6.79 & 4.96 \\
\hline Fusarium sp. & $\begin{array}{c}18.4 \\
(100.0)\end{array}$ & $\begin{array}{c}13.3 \\
(72.3)\end{array}$ & $\begin{array}{r}7.0 \\
(38.0)\end{array}$ & $\begin{array}{r}7.9 \\
(42.9)\end{array}$ & $\begin{array}{r}7.6 \\
(41.3)\end{array}$ & $\begin{array}{c}10.6 \\
(57.6)\end{array}$ & 6.07 & 4.46 & 3.26 \\
\hline Erysiphe graminis & $\begin{array}{r}62.5 \\
(100.0)\end{array}$ & $\begin{array}{c}69.1 \\
(110.6)\end{array}$ & $\begin{array}{c}37.4 \\
(59.8)\end{array}$ & $\begin{array}{c}30.5 \\
(48.8)\end{array}$ & $\begin{array}{c}38.4 \\
(61.4)\end{array}$ & $\begin{array}{c}39.4 \\
(63.0)\end{array}$ & 12.16 & 8.92 & 6.51 \\
\hline Puccinia triticina & $\begin{array}{c}2.7 \\
(100.0)\end{array}$ & $\begin{array}{c}2.8 \\
(103.7)\end{array}$ & $\begin{array}{c}1.5 \\
(55.6)\end{array}$ & $\begin{array}{c}1.5 \\
(55.6)\end{array}$ & $\begin{array}{r}0.7 \\
(25.9)\end{array}$ & $\begin{array}{c}0.8 \\
(29.6)\end{array}$ & 1.22 & 0.89 & 0.65 \\
\hline
\end{tabular}

In parentheses p. c. in relation to control. 
Table 2

Effect of the treatment of wheat with Ethrel and fungicides on the percent of injured plants by pathogenic fungi

\begin{tabular}{|c|c|c|c|c|c|c|c|c|c|}
\hline \multirow[b]{2}{*}{ Pathogen } & \multicolumn{6}{|c|}{ Treatment } & \multicolumn{3}{|c|}{ LSD at $P$} \\
\hline & $\mathrm{H}_{2} \mathrm{O}$ & Ethrel & Sportak & $\begin{array}{l}\text { Sportak } \\
+ \text { Ethrel }\end{array}$ & Bayleton & $\begin{array}{l}\text { Bayleton } \\
+ \text { Ethrel }\end{array}$ & 0.001 & 0.01 & 0.05 \\
\hline $\begin{array}{l}\text { Cercosporella } \\
\quad \text { herpotrichoides }\end{array}$ & $\begin{array}{c}60.2 \\
(100.0)\end{array}$ & $\begin{array}{c}52.2 \\
(86.7)\end{array}$ & $\begin{array}{c}54.7 \\
(90.9)\end{array}$ & $\begin{array}{c}47.2 \\
(78.4)\end{array}$ & $\begin{array}{c}56.0 \\
(93.0)\end{array}$ & $\begin{array}{c}54.5 \\
(90.5)\end{array}$ & 7.46 & 5.46 & 3.99 \\
\hline Fusarium sp. & $\begin{array}{c}29.2 \\
(100.0)\end{array}$ & $\begin{array}{l}27.0 \\
(92.5)\end{array}$ & $\begin{array}{c}14.0 \\
(47.9)\end{array}$ & $\begin{array}{c}16.2 \\
(55.5)\end{array}$ & $\begin{array}{c}20.7 \\
(70.9)\end{array}$ & $\begin{array}{c}16.7 \\
(57.2)\end{array}$ & 5.37 & 3.94 & 2.87 \\
\hline Erysiphe graminis & $\begin{array}{c}99.7 \\
(100.0)\end{array}$ & $\begin{array}{c}100.0 \\
(100.3)\end{array}$ & $\begin{array}{c}97.7 \\
(98.0)\end{array}$ & $\begin{array}{c}98.5 \\
(98.8)\end{array}$ & $\begin{array}{c}98.7 \\
(99.0)\end{array}$ & $\begin{array}{c}98.7 \\
(99.0)\end{array}$ & 15.41 & 11.31 & 8.26 \\
\hline Puccinia triticina & $\begin{array}{c}3.8 \\
(100.0)\end{array}$ & $\begin{array}{c}5.6 \\
(147.4)\end{array}$ & $\begin{array}{c}3.1 \\
(81.6)\end{array}$ & $\begin{array}{c}3.0 \\
(78.9)\end{array}$ & $\begin{array}{c}2.8 \\
(73.7)\end{array}$ & $\begin{array}{c}2.8 \\
(73.7)\end{array}$ & 1.33 & 0.97 & 0.70 \\
\hline
\end{tabular}

In parentheses p. c. in relation to control. 
des was indeed synergistic. This is clearly seen with regard to both the degree of infection (Table 1) and the percentage of plants affected (Table 2). Ethrel and Sportak showed no interaction whatever in relation to species of the genus Fusarium and to Puccinia triticina whereas in Erysiphe graminis, Ethrel, which introduced separately stimulated the fungus's development, applied in conjunction with Sportak increased its inhibitory effect. This, however, does not refer to the fungicide's effect on the percentage of plants infected. In this respect no interaction was found. As concerns the other fungi, no interaction of Ethrel and Sportak was detected in their fungistatic effect.

No interaction of Ethrel and Bayleton was found in affecting the development of the fungi under study on wheat. Significant synergistic action of these preparations was found only in relation to the percentage of plants infected by species of the genus Fusarium.

The effect of the treatment on the composition of the root mycoflora of wheat is illustrated in Figure 1. The data presented here indicate that in the rhizosphere of the plants, species of the genus Cladosporium and Trichoderma dominated, while in the rhizoplane, a strong dominance of the genus Fusarium was noted.
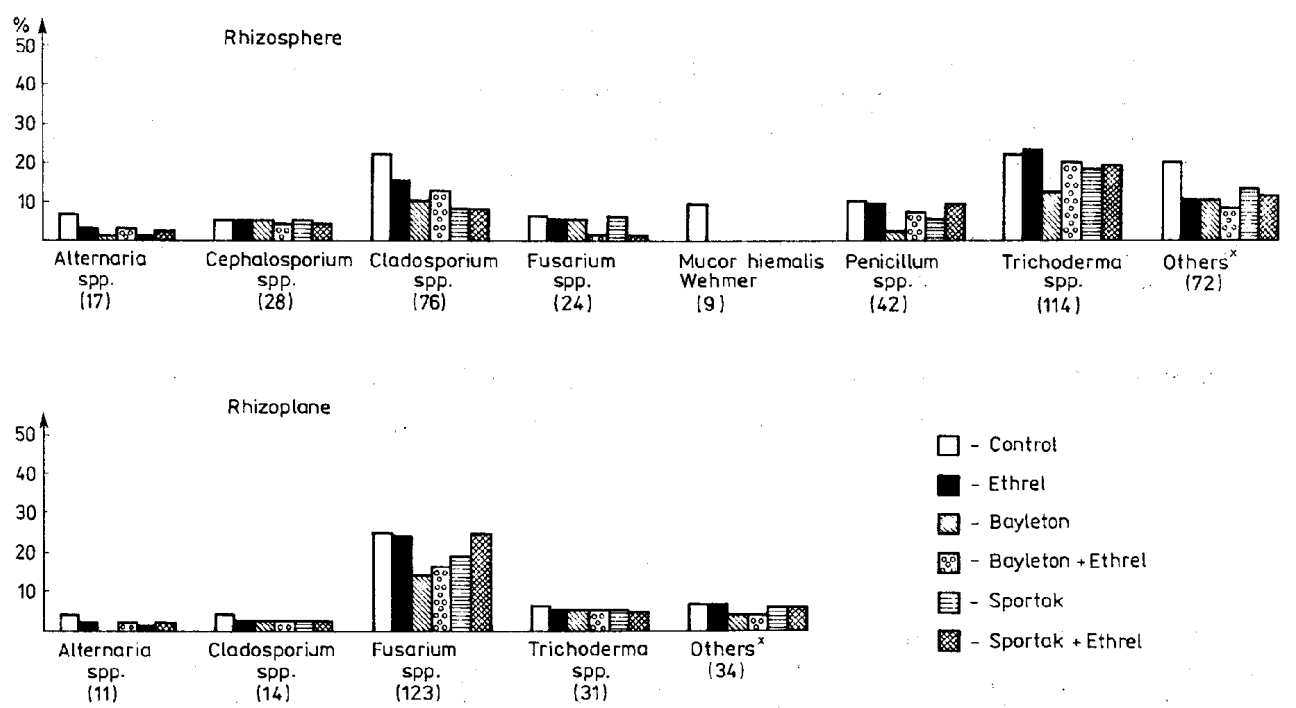

Fig. 1. Effect of treatment of wheat with Etherel and fungicides on the mycoflora composition in the root zone (in number of isolates). ${ }^{x}$ Others: Rhizosphere - Goniothyrium fuckelii Saccardo, Heterosporium terrestre R. G. Atkinson, Oidiodendron flavum Szilvinyi emend Barron, Papularia sphaerosperma (Persoon) v. Höhnel, Phoma glomerata (Corda) Wollenweber, Pyrenochaeta decipie'ns Marchal, Rhizopus oryzae Went and Gerlings, Scopulariopsis brevicaulis Bainier, Sphaeronemma spinella Kalchbrenner, Verticillium candelabrum Bonorden, fungi non sporulating. Rhizoplane - Cephalosporium charticola Lindau, Cylindrocarpon didymum (Hartung) Wollenweber, Helminthosporium graminum Rabenhorst, Papularia sphaerosperma (Persoon) v. Höhnel, Penicillium spp., fungi non sportulating. In parentheses - total number of isolates 
The treatment affected the composition of the root mycoflora only slightly, except for the fungi of the genus Mucor, which were completely eliminated from the wheat rhizosphere (17 isolates in the control). The treatment also reduced to a certain extent the occurrence of fungi of the genera Alternaria and Cladosporium in the wheat rhizosphere. Bayleton and Sportak were more effective than Ethrel. Both these fungicides also reduced the occurrence of species of the genus Penicillium in the rhizosphere.

The treatment of plants very slightly affected the mycoflora of the rhizoplane, as in the rhizosphere, it reduced to some extent the occurrence of Alternaria and Cladosporium. In the case of Alternaria, the effect of Sportak, and even more that of Bayleton, was stronger than that of Ethrel. The fungicides used separately reduced the occurrence of Fusarium in the wheat rhizoplane.

Ethrel interacted with the fungicides only in the case of fungi of the genus Fusarium in the wheat rhizosphere. Neither Ethrel nor the fungicides applied separately significantly affected the occurrence of these fungi in the rhizosphere, whereas used jointly they reduced it.

\section{REFERENCES}

Hoffmann G., 1978. Composan- ein Intensivierungsfaktor in der Winter roggenproduction. Tag. Br. Akad. Landwirtschaft-Wiss. DDR, Berlin 263: 5-8.

Michniewicz M., Rożej A., Czerwińska E., Kruszka G., 1986. Effect of Ethrel treatment of wheat on the susceptibility to fungal diseases and on the root zone mycoflora of this plant. Acta Agrobot. 39: 16-22.

Nickell L. G., 1982. Plant growth regulators. Agricultural uses. Springer Verlag, Berlin Heidelberg, New York.

\section{Wpływ stosowania Ethrelu łącznie $z$ fungicydami w uprawie pszenicy, na porażenie roślin przez grzyby pasożytnicze \\ i na skład mykoflory korzeniowej}

\section{Streszczenie}

Pszenicę ozimą odmiany Grana uprawianą w warunkach polowych, będąca we wczesnej fazie tworzenia się pierwszego kolanka, opryskiwano roztworem Ethrelu $\left(0,35 \mathrm{ml} / \mathrm{m}^{2}\right)$ oraz fungicydami: Sportak $45 \mathrm{EC}\left(0,1 \mathrm{ml} / \mathrm{m}^{2}\right)$ i Bayleton Triple $\left(0.2 \mathrm{~g} / \mathrm{m}^{2}\right)$ - oddzielnie oraz lącznie z Ethrelem. Stwierdzono, że traktowanie roślin Ethrelem zmniejszało wrażliwość roślin na porażenie przez Cercosporella herpotrichoides i gatunki z rodzaju Fusarium. Fungicydy były bardziej aktywne i zmniejszały także wrażliwość na porażenie przez Erysiphe graminis i Puccinia triticina. Fungistatyczne dzialanie Ethrelu i Spartaku okazało się synergistyczne tylko w przypadku Cercosporella herrpotrpochoides. Etherel $\mathrm{i}$ fungicydy w niewielkim stopniu wpływały na mykoflorę strefy korzeniowej, jednakże całkowicie eliminowały grzyby z rodzaju Mucor w ryzosferze i zmniejszały udzial izolatów $\mathrm{z}$ rodzaju Alternaria i Cladosporium $\mathrm{w}$ ryzosferze i ryzoplanie pszenicy. Fungicydy byly bardziej aktywne aniżeli Ethrel. Stwierdzono interakcje Ethrelu i Sportaku w eliminowaniu grzybów z rodzaju Fusarium w ryzosferze roślin. 